\title{
Treatment of two Asiatic black bears (Ursus thibetanus) with severe injuries and their subsequent release into the wild: a case report
}

Dong-Hyuk Jeong ${ }^{1 \dagger}$, Kwangsik Jang ${ }^{2 \dagger}$, Jeong-Jin Yang ${ }^{1}$, Joo-Yeul Choi ${ }^{1}$, Seung-Hyo Lim ${ }^{1}$, Seong-Chan Yeon ${ }^{3}$, Kyung Mi Shim², Se Eun Kim² ${ }^{2^{*}}$ and Seong Soo Kang ${ }^{2^{*}}$ (D)

\begin{abstract}
Background: The rehabilitation of injured wildlife and their subsequent release into the wild is a humane act as well as important in wildlife conservation. However, little is known about the animals' fate after release. Therefore, to address these uncertainties, it is essential to adequately describe how the injured animals were treated and managed before releasing into the wild; moreover, post-release monitoring should also be performed. Herein, we document for the first time the process of rescue, surgery, and rehabilitation of severely injured Asiatic black bears (Ursus thibetanus; endangered species in South Korea) and their fate after returning to the wild.

Case presentation: A six-year-old female (bear-01) and a three-year-old male (bear-02) bears were injured by an illegal snare and collision with a bus, respectively. Bear-01 had broad muscle necrosis and ruptures from the snared ankle on the right thoracic limb, with myiasis, and elbow disarticulation was performed. In bear-02, a non-reducible comminuted fracture of the left humerus was confirmed radiologically, and the operation was performed by using dual plate fixation with hydroxyapatite and recombinant human bone morphogenetic protein-2. The bear-01 and -02 were completely healed approximately 30 and 60 days after surgery, respectively. After that, they underwent rehabilitation for 8 and 25 days, respectively, in an outdoor enclosure similar to their natural habitat. Bear-01 and -02 were released into the wild after 45 and 99 days after surgery, respectively, and their mean daily movement distance during the first 30 days after releasing was $2.9 \pm 2.1$ and $1.3 \pm 1.6 \mathrm{~km}$, respectively. The annual mean $95 \%$ Kernel home-range size of bear-01 and bear-02 was 265.8 and $486.9 \mathrm{~km}^{2}$, respectively. They hibernated every winter, gained weight, gave birth to cubs (bear-01), were not found to have any abnormalities in the veterinary tests, and were not involved in any conflicts with humans after returning to the wild.

(Continued on next page)
\end{abstract}

\footnotetext{
*Correspondence: ksevet@chonnam.ac.kr; vetkang@chonnam.ac.kr

${ }^{\dagger}$ Dong-Hyuk Jeong and Kwangsik Jang contributed equally to this work. ${ }^{2}$ Department of Veterinary Surgery and Biomaterial R\&BD Center, College of Veterinary Medicine, Chonnam National University, Gwanju 61186, Republic of Korea

Full list of author information is available at the end of the article
}

(c) The Author(s). 2021 Open Access This article is licensed under a Creative Commons Attribution 4.0 International License, which permits use, sharing, adaptation, distribution and reproduction in any medium or format, as long as you give appropriate credit to the original author(s) and the source, provide a link to the Creative Commons licence, and indicate if changes were made. The images or other third party material in this article are included in the article's Creative Commons licence, unless indicated otherwise in a credit line to the material. If material is not included in the article's Creative Commons licence and your intended use is not permitted by statutory regulation or exceeds the permitted use, you will need to obtain permission directly from the copyright holder. To view a copy of this licence, visit http://creativecommons.org/licenses/by/4.0/. The Creative Commons Public Domain Dedication waiver (http://creativecommons.org/publicdomain/zero/1.0/) applies to the data made available in this article, unless otherwise stated in a credit line to the data. 
(Continued from previous page)

Conclusions: Bears without one leg or those with dual plates could adapt well in their natural habitat, which shows that our surgical and post-operative treatments were effective. Additionally, minimizing human contact and observing/evaluating behavior during the rehabilitation is essential in reducing human-bear conflicts after release.

Keywords: Asiatic black bears, Wildlife, Injury, Amputation, Dual plate fixation, rhBMP-2, Rehabilitation, Reintroduction

\section{Background}

The rehabilitation and returning to the wild of injured or ill wildlife is a humane act as well as being an important part of wildlife conservation; however, the release of injured animals back into the wild is often controversial [1-3]. Since wildlife rehabilitation and release are a blend of veterinary medicine, natural history, ecology, and animal behavior [4], they are occasionally performed without adequate data on animal husbandry, nutrition and restraint techniques, disease susceptibility, biomedical parameters, and specific medical and surgical techniques [5-7]. In addition, little is known about the animals' fate after release, their impact on the local receiving population, the outcome of their health, or whether their release into the wild was successful. Population-level risks may also occur if the released animals are more likely to become involved in humanwildlife conflicts or to spread diseases $[3,8]$. Therefore, to address these uncertainties, post-release monitoring should be conducted to clarify the feasibility of this approach for wildlife conservation [9]. Beecham et al. [10] reported that captive-reared bears released to the wild met the requirements for success concerning survival rates, human conflict levels, and reproduction in the wild. However, all bears accepted into captive-rearing facilities in the study were orphaned cubs without severe injuries. The combination of a series of treatment, rehabilitation, release, and post-release monitoring of adult bears with severe injuries has been rarely been reported.

The Asiatic black bear (Ursus thibetanus; ABB) is a vulnerable species according to the Red List by the International Union for Conservation of Nature [11], and a reintroduction project to establish a self-sustaining $\mathrm{ABB}$ population was initiated in 2002 in the Republic of Korea [12]. Highlights of the project include the introduction and releasing into the wild of ABB from China, North Korea and Russia, research and monitoring of these individuals, and implementation of public awareness-raising activities to protect species [12]. The number of bears, which was only about 5 at the beginning of the project, has increased to 69 as of 2020, which is considered a very successful restoration project [13]. We focused on 2 severely injured ABB that were rehabilitated and released into the wild in 2017 and 2018. The study areas were Jirisan National Park, Gayasan National
Park, Mt Sudo, and its surrounding areas where the restoration project of Asiatic black bears is underway $\left(35^{\circ} 12^{\prime} 40^{\prime \prime}-35^{\circ} 56^{\prime} 04^{\prime \prime} \mathrm{N}\right.$ and $127^{\circ} 27^{\prime} 20^{\prime \prime}$ - $128^{\circ} 08^{\prime}$ $\left.18^{\prime \prime} \mathrm{E}\right)$. In this context, our releases were intended to reinforce the local $\mathrm{ABB}$ population, adding 2 individuals that might become breeders into the resident population. In addition, a series of emergency rescue, treatment, rehabilitation, release, and post-release monitoring conducted in our cases might represent one of the most active wildlife conservation efforts. Herein, we documented the process of rescue, surgery, rehabilitation of severely injured $\mathrm{ABBs}$ which were introduced from Russia to Jirisan National Park in South Korea in 2012 and 2016, and their fate after returning to the wild. All work reported in this study was carried out under license from the Korea National Park Service (permits: SRTI-1727, 2783, 2924, and 3301).

\section{Case presentation \\ Case 1}

Six-year-old female ABB (bear-01) had been monitored through radio-tracking since the first release at the age of 1 year for the restoration of endangered ABB in South Korea, was found severely injured by an illegal snare trap to catch wild boars on September 08, 2017.

The bear was held in the trap for less than 2 days ( 2 days ago, it was confirmed by radio tracking that the bear was in a place other than the trap location), and it was immobilized with zolazepam-tiletamine $(2 \mathrm{mg} / \mathrm{kg}$; Zoletil $50^{\circ}$, Virbac, Carros, France) and medetomidine (0.04 mg/kg; Domitor ${ }^{\circ}$, Pfizer, New York, NY, USA) using a $\mathrm{CO}_{2}$-powered gun (Dan-inject, Børkop, Denmark) for removal of the trap. Then, the bear was transported to the Wildlife Medical Center of Korea National Park Service for clinical assistance and rehabilitation, and there was no supplementary injection of anesthetics during the transportation. The animal weighed $104 \mathrm{~kg}$ at capture, and the examination revealed broad muscle necrosis and rupture of the snared ankle on the right thoracic limb with myiasis (Fig. 1a); blood tests showed increased aspartate aminotransferase (AST) and creatine phosphokinase. Thus, surgical amputation of the injured limb was required and we operated on September 09, 2017. The animal was immobilized with the standard method prescribed for ABB by Jeong et al. 


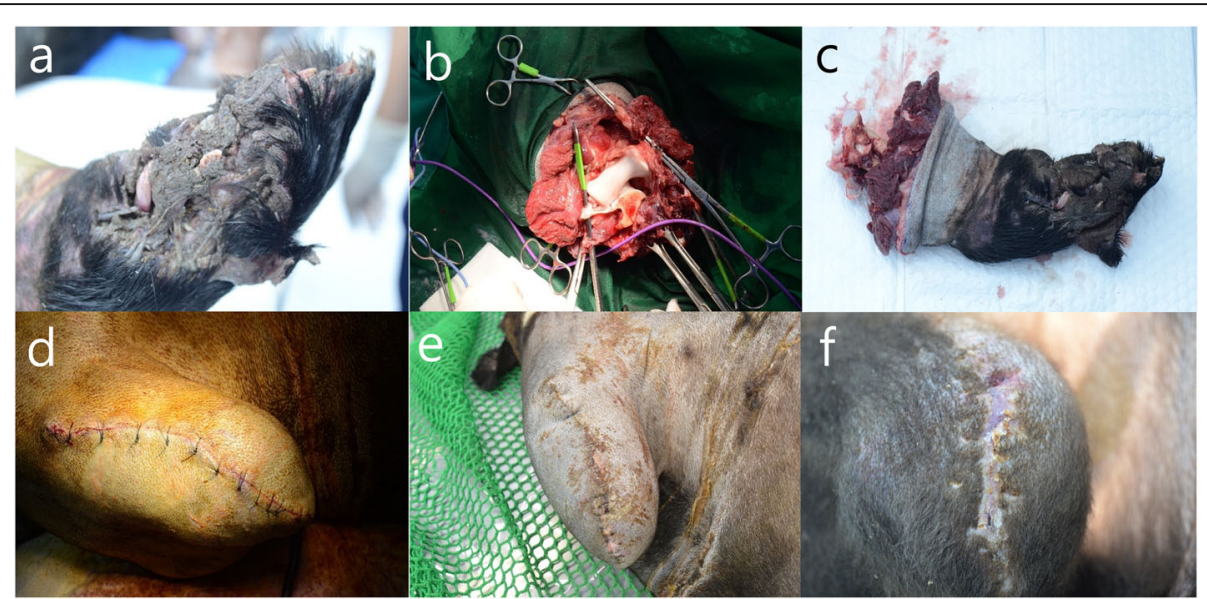

Fig. 1 The amputation of the elbow joint in the Asiatic black bear (bear-01). $\mathbf{a}$, before the surgery; $\mathbf{b}$, exposed trochlea and capitulum of right humerus; $\mathbf{c}$, amputated right thoracic limb; $\mathbf{d}$, immediately after surgery; $\mathbf{e}, 5$ days after surgery; $\mathbf{f}$, 37 days after surgery

[14]. Briefly, intramuscular injections of zolazepamtiletamine $\left(2 \mathrm{mg} / \mathrm{kg} ;\right.$ Zoletil $\left.50^{\circ}\right)$ and medetomidine $\left(0.04 \mathrm{mg} / \mathrm{kg}\right.$; Domitor $\left.{ }^{\bullet}\right)$ was administered from a distance of $5 \mathrm{~m}$ using a $\mathrm{CO}_{2}$-powered gun (Dan-inject); anesthesia was maintained with isoflurane (Terrell ${ }^{\circ}$, Piramal Critical Care, Bethlehem, PA, USA) in 100\% oxygen $(4 \mathrm{~L} / \mathrm{min})$ administered via a $10-\mathrm{mm}$ endotracheal tube intubation in a circle rebreathing system. After intubation, the bear received injections of glycopyrrolate $\left(0.01 \mathrm{mg} / \mathrm{kg}\right.$, IM; Mobinul ${ }^{\circ}$, Myungmoon Pharmaceutical Co., Ltd., Seoul, South Korea), cefovecin sodium $(8 \mathrm{mg} /$ kg, SC; Convenia ${ }^{\circ}$ Zoetis, Parsippany, NJ, USA), tramadol (2 mg/kg, IM; Humedix Tramadol HCl INJ. ${ }^{\circ}$, Huons Co., Ltd., Seongnam, South Korea), and meloxicam (0.2 $\mathrm{mg} / \mathrm{kg}$, SC; Metacam ${ }^{\circ}$, Boehringer Ingelheim, St. Joseph, MO, USA). Lactated Ringer's solution (Hartmann's Sol., Daihan Pharmaceutical Co., Ltd., Seoul, South Korea) was administered intravenously at a rate of $10 \mathrm{ml} / \mathrm{kg}$ per hr. In addition, vital signs such as heart rate, respiratory rate, peripheral capillary oxygen saturation $\left(\mathrm{SpO}_{2}\right)$, rectal temperature, non-invasive blood pressure, and end-tidal carbon dioxide partial pressure $\left(\mathrm{ETCO}_{2}\right)$ were monitored with a dedicated monitor (Datex-Ohmeda S/5, GE Healthcare Life Science, Helsinki, Finland).

The elbow disarticulation was performed and the procedure followed the method described by Winkler [15] and Morrey [16], with some modifications (Fig. 1b-d). Briefly, equal anterior and posterior skin flaps were created, beginning at the level of the humeral epicondyles. The incisions are extended distally, $5 \mathrm{~cm}$ distal to the tip of the olecranon posteriorly, and down to a point just distal to the insertion of the biceps tendon anteriorly. The lacertus fibrosus was divided and all the pronator attachments from the medial epicondyle were released. Then, the radial and ulnar nerves were transected and allowed to retract into the proximal wound. The large vessels were doubly ligated with 3-0 polyethylene terephthalate (Ti-CRON Polyester sutures, Covidien, Dublin, Ireland) and transected by an electro-thermal vessel sealing device (EVSD; LigaSure Max, Covidien, Dublin, Ireland); the small vessels were transected using the device alone, without ligation. The anterior, radiohumeral, and ulnohumeral capsules were divided, and trochlea and capitulum of the humerus were exposed. Then, the radius was disarticulated; however, it was difficult to disarticulate the ulna. Therefore, we performed an ostectomy of the ulna at the level of the trochlea, retaining the olecranon of the ulna, using an electric saw (BH 100S, IMEDICOM, Gunpo, South Korea). The posterior flap was moved medially and sutured continuously to the soft tissues of the medial epicondyle with 2-0 polyglyconate (Maxon ${ }^{\circ}$, Covidien, Dublin, Ireland). The humerus was closed with a flap of the brachialis, biceps, and triceps, and the skin was closed with a simple interrupted suture of 1-0 nylon (Blue nylon NB125, Ailee, Busan, Korea) and skin stapler (Appose ULC $35 \mathrm{~W}$, Medtronic, Minneapolis, MN, USA). After transportation to the rehabilitation room, $0.2 \mathrm{mg} / \mathrm{kg}$ atipamezole (Antisedan ${ }^{\circ}$, Pfizer, New York, NY, USA) was injected intravenously, and the animal recovered from general anesthesia after a duration of 337 min uneventfully in a metal holding cage $(2.2 \times 0.8 \times 1.2 \mathrm{~m})$. The total surgery time was $268 \mathrm{~min}$, and all parameters of intraoperative anesthetic evaluation were within the normal ranges (mean respiratory rate, $13.9 \pm 1.7$ breaths $/ \mathrm{min}$; mean heart rate, $54.4 \pm 8.1$ beats $/ \mathrm{min}$; mean rectal temperature, $35.9 \pm 0.7^{\circ} \mathrm{C}$; mean blood pressure, $91.1 \pm$ $11.8 \mathrm{mmHg}$; mean $\mathrm{SpO}_{2}, 97.9 \pm 4.5 \%$; mean $\mathrm{ETCO}_{2}$, $30.5 \pm 1.3 \%)$. The bear-01 stayed in the holding cage for 22 days and was visited twice daily for approximately 5 min for feeding (the first 5 days after the surgery) veterinary prescription diet (Recovery, Royal Canin, 
Aimargues, France) and fruits with honey; from days 622, acorns, chestnuts, fruits, vegetables, sweet potatoes, and commercial feed (Omnivore Diet Dry, ZuPreem, Mission, TX, USA), and medication $(0.1 \mathrm{mg} / \mathrm{kg}$ meloxicam with food once a day for 14 days orally) were administered. No post-operative complications were observed during the stay.

On October 01, 2017, the bear-01 was moved to an indoor room $(3 \times 4 \times 3 \mathrm{~m}$; tiled floors and walls; direct sunlight via a $1 \mathrm{~m} \times 1.4 \mathrm{~m}$ window on the roof) for light exercise and recovery and stayed there for 15 days. On the 37th day after the surgery, the surgical site was examined and the skin staples were removed under general anesthesia (Fig. 1f). The examination confirmed that the surgical site had recovered completely; on the same day, we moved the animal for rehabilitation to an outdoor enclosure $\left(5489 \mathrm{~m}^{2}\right)$, established a closed-circuit television system (CCTV; IDR-H4032, IDIS Korea, Daejeon, South Korea) in the forest, which was similar to the bear's natural habitat. While it was there for 8 days, we observed its movement and behavior through CCTV without any direct contact and confirmed that the bear climbed up and down the trees without difficulty and found its natural foods, and ate them in the enclosure. To see how the bear reacted to humans, two people went into the enclosure with the bear's favorite foods (apple, honey, fish and chestnut); immediately after their entrance, the bear avoided the people and moved away from them. Additionally, we established an portable electric fence $(3 \times 3 \mathrm{~m})$ in the enclosure and placed some foods inside the fence (Fig. 4a) to see how the bear reacted to the fence; the fence was non-invasive and safe for bears weighing over $100 \mathrm{~kg}$ because the average voltage of the electric fence was only $4 \mathrm{~kW}$ and it passes current for $0.3 \mathrm{~s}$ once a second. As a result, the bear approached the fence and tried to enter during the night on three occasions, but received an electric shock. Subsequently, the bear roamed around it for about $5 \mathrm{~min}$, but the bear did not pass beyond the fence (Fig. 4b). Considering these behaviors (avoidance of humans and recognizing the electric fence), activities, and the bear's general health condition, we concluded that the bear could be returned to its natural habitat. Consequently, we released the bear, fitted with a radio transmitter (M3620, ATS, Isanti, MN, USA), into Jirisan National Park on October 24, 2017 (45 days after surgery), and radio-tracked it every day for about 2 years through a triangulation method [17] and obtained 435 locations. In addition, we accompanied a field survey (camera trapping and hibernation site survey) as well. We estimated daily movement distances (DMD) as the straight-line distances $(\mathrm{km})$ between two consecutive days and analyzed the area covered by the bear using minimum convex polygons (MCP) with 95\% and kernel with 95 and
$50 \%$ of locations using a geographic information system (ArcGIS v.10.1, Environmental Systems Research Institute, Inc., Redlands, CA, USA). Telemetry error was estimated by comparing the estimated locations of nine test transmitters by five experts with more than 6 years of radio-tracking experience to their actual locations. The locations of the test transmitters were changed once, thus generating 18 different locations. Consequently, 90 radio-locations for telemetry error $(5$ people $\times 18$ locations) were obtained and the average telemetry error was $44.7 \pm 39.6 \mathrm{~m}$. The mean DMD, 95\% MCP, 95 and $50 \%$ kernel home ranges for 30 days between the day they were released and the day before hibernation (November 25 , 2017; the hibernating day was defined as the first day of the period in which the location change within $100 \mathrm{~m}$ lasts continuously for 5 days or more) were $1.3 \pm 1.6 \mathrm{~km}$, $9.4 \mathrm{~km}^{2}, 56.9 \mathrm{~km}^{2}$, and $10.5 \mathrm{~km}^{2}$, respectively (Figure or Table 1). On the March 28, 2018, we surveyed the den site and observed bear-01, which was playing with two cubs (Fig. 4d, e). Then, they stayed there until May 15, 2018, mean DMD, 95\% MCP, 95 and 50\% kernel home ranges were $1.6 \pm 1.8 \mathrm{~km}, 41.7 \mathrm{~km}^{2}, 138.7 \mathrm{~km}^{2}$, and 30.5 $\mathrm{km}^{2}$ in summer (June to August), and those in autumn (September to November) 2018 were $2.1 \pm 2.2 \mathrm{~km}, 56.9$ $\mathrm{km}^{2}, 189.9 \mathrm{~km}^{2}$, and $53.5 \mathrm{~km}^{2}$, respectively (Figure or Table 1). Between January 15 and February 20, 2019, the bear-01 hibernated, and it was re-captured on the 10th of August 2019 to exchange the transmitter by a culvert trap. When bear-01 was captured, it weighed $105 \mathrm{~kg}$, and through camera trapping and field surveys we could not find any evidence that the bear was living with the yearlings. The blood sample was collected from the jugular vein, and all blood chemistry and complete blood cell count $(\mathrm{CBC})$ test values were within normal ranges. The mean DMD, seasonal, and annual home ranges in 2019 are shown in Table 1. On the 18th of May 2020, we confirmed bear-01 with two newborn cubs through camera trapping (Fig. 4f).

\section{Case 2}

A three-year-old male bear (bear-02), which was managed by the reintroduction program of $\mathrm{ABB}$, was rescued from a traffic accident on the May 11, 2018 (bear-02 moved to the mountains after the collision with a bus on the 5th of May and we were able to capture him on the 11th of May). When captured, the animal weighed 110 $\mathrm{kg}$ and seemed to have a fracture of the left humerus. This bear was transferred to the same veterinary team and a non-reducible comminuted fracture of the left humerus was confirmed radiographically (Fig. 2a). Blood examinations revealed increased white blood cells, AST, and C-reactive protein. On the 17th of May (12 days after the accident), preoperative radiographs of both the injured and the contralateral humerus were obtained. 
Table 1 The summary of rescue, treatment, rehabilitation, release, and post-release monitoring in two severely injured Asiatic black bears (Ursus thibetanus) in the Republic of Korea

\begin{tabular}{|c|c|c|c|c|c|c|}
\hline \multicolumn{7}{|c|}{ Bear-01 } \\
\hline Sex & Age & Rescue & Surgery & Recovery & Rehabilitation & Release \\
\hline Female & $\begin{array}{l}6 \\
\text { years }\end{array}$ & $\begin{array}{l}104 \mathrm{~kg} \text {, broad muscle necrosis } \\
\text { and ruptures of the snared } \\
\text { ankle on the right thoracic } \\
\text { limb with myiasis }(8 / 9 / 2017)\end{array}$ & $\begin{array}{l}\text { The elbow disarticulation } \\
(9 / 9 / 2017)\end{array}$ & $\begin{array}{l}\text { 1. Small } \\
\text { cage ( } 22 \\
\text { days) } \\
\text { 2. Indoor } \\
\text { room (15 } \\
\text { days) } \\
\text { Completely } \\
\text { healed } \\
\text { around } 30 \\
\text { days after } \\
\text { surgery }\end{array}$ & $\begin{array}{l}\text { Preparation for } \\
\text { returning to nature } \\
\text { and behavior } \\
\text { assessment in outdoor } \\
\text { enclosure ( } 8 \text { days) }\end{array}$ & $\begin{array}{l}\text { Jirisan NP } \\
\text { (45 days after surgery; 24/10/ } \\
\text { 2017) }\end{array}$ \\
\hline \multicolumn{7}{|c|}{ Post-release monitoring (radio-tracking and field survey) } \\
\hline \multicolumn{2}{|c|}{$\mathrm{DMD}(\mathrm{km})$} & HR for $95 \% \mathrm{MCP}\left(\mathrm{km}^{2}\right)$ & HR for $95 \%$ Kernel $\left(\mathrm{km}^{2}\right)$ & \multicolumn{2}{|c|}{ HR for $50 \%$ Kernel $\left(\mathrm{km}^{2}\right)$} & Note \\
\hline \multicolumn{2}{|c|}{$\begin{array}{l}\text { The first } 30 \\
\text { days: } 1.3 \pm 1.6 \\
\text { Summer } \\
\text { 2018: } 1.6 \pm 1.8 \\
\text { Autumn } 2018: \\
2.1 \pm 2.2 \\
\text { Spring } 2019 \text { : } \\
1.6 \pm 2.3 \\
\text { Summer } \\
2019: 2.8 \pm 2.4 \\
\text { Autumn } 2019 \text { : } \\
1.1 \pm 1.6\end{array}$} & $\begin{array}{l}\text { The first } 30 \text { days: } 9.4 \\
\text { Summer 2018: } 41.7 \\
\text { Autumn 2018: } 56.9 \\
\text { Spring 2019: } 50.1 \\
\text { Summer 2019: } 72.5 \\
\text { Autumn 2019: } 82.4 \\
\text { Annual 2019: } 68.3\end{array}$ & $\begin{array}{l}\text { The first } 30 \text { days: } 56.9 \\
\text { Summer 2018: } 138.7 \\
\text { Autumn 2018: } 189.9 \\
\text { Spring 2019: 229.6 } \\
\text { Summer 2019: } 250.1 \\
\text { Autumn 2019: } 317.7 \\
\text { Annual 2019: } 265.8\end{array}$ & \multicolumn{2}{|c|}{$\begin{array}{l}\text { The first } 30 \text { days: } 10.5 \\
\text { Summer 2018: } 30.5 \\
\text { Autumn 2018: } 53.3 \\
\text { Spring 2019: } 64.2 \\
\text { Summer 2019: } 67.5 \\
\text { Autumn 2019: } 71.6 \\
\text { Annual 2019: } 67.8\end{array}$} & $\begin{array}{l}\text { Parturition of four cubs after } \\
\text { releasing into the wild (two in } \\
2018 \text {, two in 2020; confirmed by } \\
\text { unmanned camera and field } \\
\text { survey) } \\
105 \mathrm{~kg} \text { (confirmed by capturing } \\
\text { it with a culvert trap, 10/8/2019) }\end{array}$ \\
\hline \multicolumn{7}{|c|}{ Bear-02 } \\
\hline Sex & Age & Rescue & Surgery & Recovery & Rehabilitation & Release \\
\hline Male & $\begin{array}{l}3 \\
\text { years }\end{array}$ & $\begin{array}{l}110 \mathrm{~kg} \text {, comminuted fracture } \\
\text { of left humerus (8/9/2017) }\end{array}$ & $\begin{array}{l}\text { Fixation of two locking } \\
\text { compression plates with } \\
\text { screws + autologous } \\
\text { bone chips + rhBMP-2 } \\
(17 / 5 / 2018)\end{array}$ & $\begin{array}{l}\text { 1. Small } \\
\text { cage (48 } \\
\text { days) } \\
\text { 2. Indoor } \\
\text { room (26 } \\
\text { days) } \\
\text { Completely } \\
\text { healed } \\
\text { around } 60 \\
\text { days after } \\
\text { surgery }\end{array}$ & $\begin{array}{l}\text { Preparation for } \\
\text { returning to nature } \\
\text { and behavior } \\
\text { assessment in outdoor } \\
\text { enclosure ( } 25 \text { days) }\end{array}$ & $\begin{array}{l}\text { Jirisan NP } \\
\text { ( } 99 \text { days after surgery; 26/8/ } \\
\text { 2018) }\end{array}$ \\
\hline \multicolumn{7}{|c|}{ Post-release monitoring (radio-tracking and field survey) } \\
\hline \multicolumn{2}{|c|}{$\mathrm{DMD}(\mathrm{km})$} & HR for $95 \% \mathrm{MCP}\left(\mathrm{km}^{2}\right)$ & HR for $95 \%$ Kernel $\left(\mathrm{km}^{2}\right)$ & \multicolumn{2}{|c|}{ HR for $50 \%$ Kernel $\left(\mathrm{km}^{2}\right)$} & Note \\
\hline \multicolumn{2}{|c|}{$\begin{array}{l}\text { The first } 30 \\
\text { days: } 2.9 \pm 2.1 \\
\text { Autumn } 2018 \text { : } \\
1.9 \pm 1.7 \\
\text { Spring 2019: } \\
1.4 \pm 2.1 \\
\text { Summer } \\
2019: 3.7 \pm 2.5 \\
\text { Autumn } 2019 \text { : } \\
0.8 \pm 1.0\end{array}$} & $\begin{array}{l}\text { The first } 30 \text { days: } 36.9 \\
\text { Autumn 2018: } 106.7 \\
\text { Spring 2019: } 95.6 \\
\text { Summer 2019: } 419.6 \\
\text { Autumn 2019: } 24.6 \\
\text { Annual 2019: } 179.9\end{array}$ & $\begin{array}{l}\text { The first } 30 \text { days: } 170.6 \\
\text { Autumn 2018: } 215.8 \\
\text { Spring 2019: } 247.1 \\
\text { Summer 2019: } 1131.1 \\
\text { Autumn 2019: } 82.5 \\
\text { Annual 2019: } 486.9\end{array}$ & \multicolumn{2}{|c|}{$\begin{array}{l}\text { The first } 30 \text { days: } 40.5 \\
\text { Autumn 2018: } 59.2 \\
\text { Spring 2019: } 53.4 \\
\text { Summer 2019: } 213.1 \\
\text { Autumn 2019: } 19.2 \\
\text { Annual 2019: } 95.2\end{array}$} & $\begin{array}{l}143 \mathrm{~kg} \text { (confirmed by winter den } \\
\text { capturing, 26/2/2018) } \\
165 \mathrm{~kg} \text { (confirmed by winter den } \\
\text { capturing, 27/2/2019) }\end{array}$ \\
\hline
\end{tabular}

Abbreviations: NP National Park; DMD daily movement distance as the straight-line distance between consecutive 2 days; $H R$ home range; $M C P$ minimum convex polygons; rhBMP-2, synthetic hydroxyapatites, and recombinant human bone morphogenetic protein-2. Spring, summer, and autumn are March to June, June to August, and September to November, respectively. The DMD was presented as mean \pm standard deviation

From these radiographs, a plate of the appropriate length was selected in an attempt to span the entire length of the humerus. Immobilization and monitoring of vital signs were followed by the same procedures used for bear-01. Bear-02 was placed in a supine position and we approached laterally for the surgery. A longitudinal skin incision was made from the center of the deltoid insertion to the lateral epicondyle, and the lateral head of the triceps was exposed by the insertion of the brachial fascia. The humerus was exposed by elevation of the 


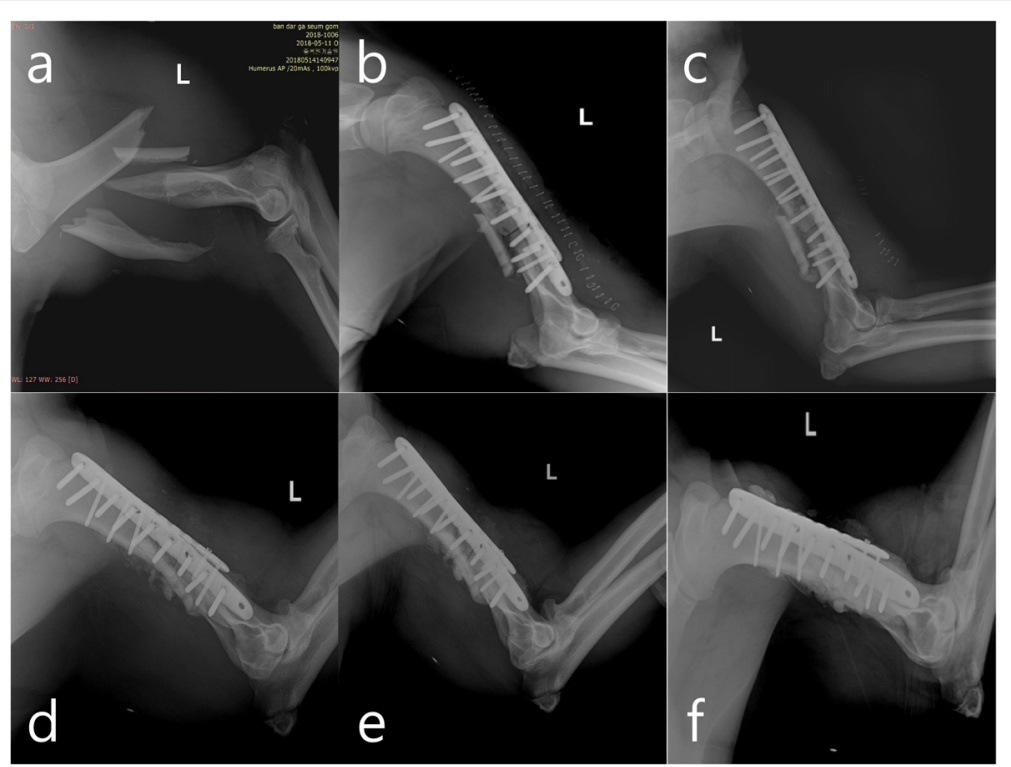

Fig. 2 Lateral radiographs of the humerus in the Asiatic black bear (bear-02). a, comminuted fracture before surgery; $\mathbf{b}$, immediately after surgery; c, 21 days after surgery; $\mathbf{d}, 34$ days after surgery; e, 48 days after surgery; $\mathbf{f}, 62$ days after surgery

brachialis and triceps from the lateral intramuscular septum. We tried to remove a bone fragment that was lodged in the deep medial head of the triceps and repair the alignment of the humerus; however, it was impossible because of the exuberant granulations and muscular contraction. Thus, we only cut the sharp edge of the broken humerus using an electric surgical saw (BH 100S, IMEDICOM, Gunpo, South Korea) without removal of the bone fragment and then we repaired the alignment of the humerus. Then, a 10 holes' 5.0 locking compression plate (LCP; APIS 157-18,110, TDM, Inc., Gwangju, South Korea) with 10 locking head screws (32 $\mathrm{mm}, 1 ; 34 \mathrm{~mm}, 1 ; 36 \mathrm{~mm}, 3 ; 38 \mathrm{~mm}, 1 ; 40 \mathrm{~mm}, 2 ; 48$ $\mathrm{mm}, 2$ ) and a 10 holes' 4.0 LCP (APIS 194-10,310, TDM, Inc., Gwangju, South Korea) with 5 locking head screws $(26 \mathrm{~mm}, 36 \mathrm{~mm}, 38 \mathrm{~mm}, 40 \mathrm{~mm}$ and $42 \mathrm{~mm})$ were used for double-plate fixation (anterior and lateral surfaces of the humerus), respectively (Fig. 3). In

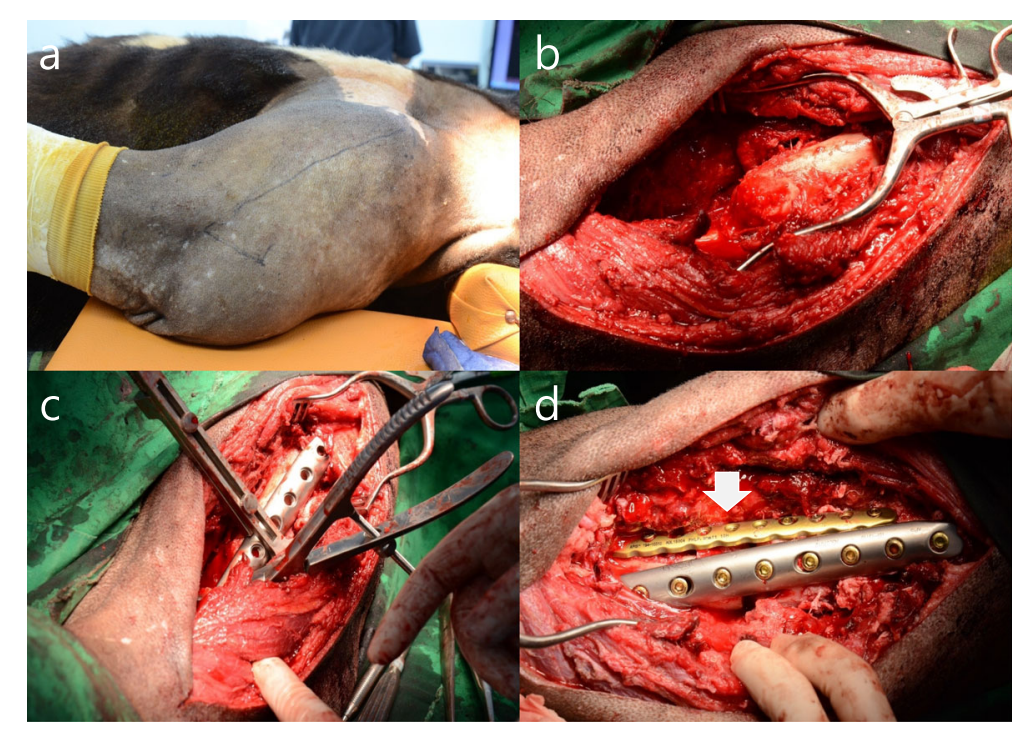

Fig. 3 The treatment of humoral fracture using dual plate fixation in the Asiatic black bear (bear-02). a, lateral approach and incision line; $\mathbf{b}$, fractured humerus; c, lateral application of 10 holes' 5.0 locking compression plate with 10 screws (32 mm, 1; $34 \mathrm{~mm}, 1 ; 36 \mathrm{~mm}, 3 ; 38 \mathrm{~mm}, 1 ; 40$ $\mathrm{mm}, 2 ; 48 \mathrm{~mm}, 2) ; \mathbf{d}$, anterior application of 4.0 locking compression plate with 5 screws ( $26 \mathrm{~mm}, 36 \mathrm{~mm}, 38 \mathrm{~mm}, 40 \mathrm{~mm}$ and $42 \mathrm{~mm}$ ), white arrow 
addition, autologous bone chips (the pieces cut from the edge of fractured humerus by surgical saw were crushed in a mortar), synthetic hydroxyapatite, and recombinant human bone morphogenetic protein-2 (rhBMP-2; NOVISIS $^{\oplus}$, CGBIO, Inc., Seungnam, South Korea) were mixed according to the manufacturer's manual and it was filled in the bone defect areas. The muscles and soft tissue were sutured continuously with 2-0 polyglyconate (Covidien Maxon sutures, Covidien, Dublin, Ireland) and the skin was closed with a skin stapler (Appose ULC 35 W, Medtronic, Minneapolis, MN, USA). Total surgery time was $405 \mathrm{~min}$ and the duration of anesthesia was 479 min. All parameters for anesthetic evaluation during the surgery were within normal ranges (mean respiratory rate, $13.5 \pm 2.1$ breaths/min; mean heart rate, $78.6 \pm 25.6$ beats/min; mean rectal temperature, $36.4 \pm 0.5^{\circ} \mathrm{C}$; mean blood pressure, $113.1 \pm 23.8 \mathrm{mmHg}$; mean $\mathrm{SpO}_{2}, 97.9 \pm$ 4.5\%; mean $\left.\mathrm{ETCO}_{2}, 35.1 \pm 4.7 \%\right)$. Medication during and after the surgery and the post-operative management were the same as those used for bear-01, except as indicated below. Postoperatively, bear-02 recovered in a metal holding cage $(220 \times 80 \times 120 \mathrm{~cm})$ for 48 days and radiographs were acquired on the 21st, 34th, and 48th days after the surgery (Fig. 2). During this period, we confirmed the formation of a callus and an increasing density of the fracture line. Thus, on the 5th of July (48 days after the surgery), we moved bear-02 to the indoor room $(3 \times 4 \times 3 \mathrm{~m})$ for light exercise, where it recovered for 26 days. While staying in the indoor room, we acquired radiographs (on the 62nd day after the surgery) and confirmed complete healing of the fracture areas (Fig. 2). Bear-02 showed no abnormal walking, and we determined that the bear needed more free and vigorous exercise. Consequently, on the 2nd of August (74 days after surgery), we moved the animal to the outdoor enclosure in the forest for rehabilitation, and the animal stayed there another 25 days. During its stay there, the bear walked up and down the slope naturally and climbed up and down a tree easily (Fig. 4c). Additionally, the bear's behavior was evaluated in the same way by the same observers for bear-01, and bear-02 showed similar behaviors as bear-01 (active human avoidance, does not try to get through the electric fence to enter the inside where the food is (Fig. 4b) after imprinting of the electric fence). Thus, on the 27th of August, 2018 (99 days after the surgery), we released it, after fitting a radio transmitter (M3620, ATS, Isanti, MN, USA) into Mt. Sudo, Kyoungbuk province; post-release monitoring and analysis were performed as that for bear-01. During the study, we obtained 465 locations and mean DMD, 95\% MCP, 95 and 50\% kernel home ranges for the first 30 days after releasing were $2.9 \pm 2.1 \mathrm{~km}, 36.9 \mathrm{~km}^{2}, 170.6$ $\mathrm{km}^{2}$, and $40.5 \mathrm{~km}^{2}$, respectively (Table 1 ). Additionally, those in autumn 2018 were $1.9 \pm 1.7 \mathrm{~km}, 106.7 \mathrm{~km}^{2}$,

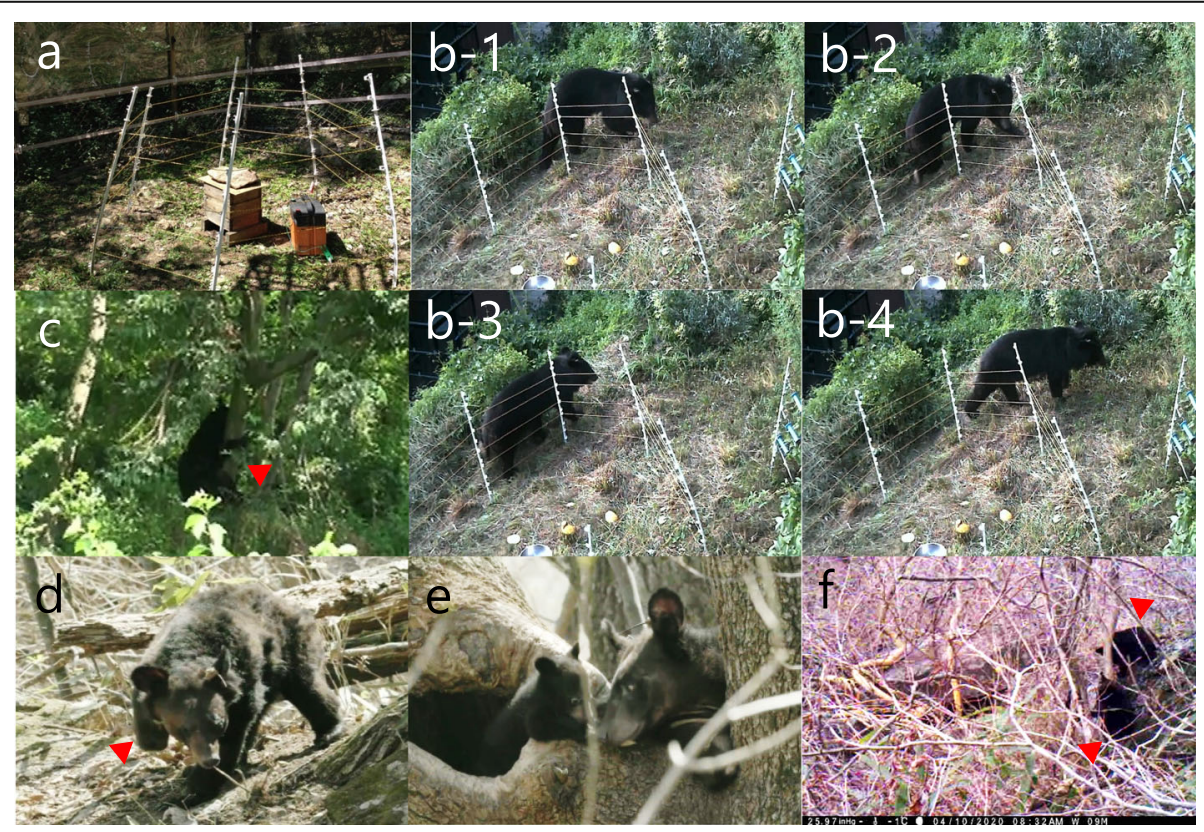

Fig. 4 Rehabilitation at the outdoor enclosure before releasing and post-releasing monitoring of two Asiatic black bears. a, portable electric fence with honey in the wooden box; $\mathbf{b}-\mathbf{1}, \mathbf{- 2}, \mathbf{- 3}$, and $\mathbf{- 4}$, the bear-02 (plates implanted) that passed by without going inside an electric fence with food during the rehabilitation period; c, the bear-02 that used all four legs to climb trees (red arrow); $\mathbf{d}$, the bear-01 with an amputated right limb (red arrow) from the first hibernation after returning to nature; $\mathbf{e}$, the bear-01 with a cub that gave birth during its first hibernation since returning to nature; $\mathbf{f}$, two cubs that gave birth during the third hibernation of bear-01 after returning to nature. The photos were taken by a smart phone camera or unmanned camera 
$215.8 \mathrm{~km}^{2}$, and $59.2 \mathrm{~km}^{2}$, respectively (Table 1 ), and bear-02 hibernated from the 27th of December 2018 until the 3rd of March 2019. During hibernation, we visited at its den site by radio-tracking and immobilized the bear there using a dart gun to replace the transmitter because of the battery's abnormal exhaustion, and its weight was $143 \mathrm{~kg}$. The mean DMD, seasonal, and annual home ranges in 2019 are shown in Table 1, and when bear-02 was captured, on the 27th of February 2020 , during the 2 nd hibernation after returning to nature, its weight was $165 \mathrm{~kg}$. The veterinary examination including blood chemistry and $\mathrm{CBC}$ in those two captures found no abnormal findings.

\section{Discussion and conclusions}

Studies have previously reported orphaned bears reared in captivity and their release into the wild [10, 18-20], but there is little information about the treatment, rehabilitation, and post-release monitoring of seriously injured bears over 3 years of age. Thus, herein we described in detail these processes; our methodologies and results will be a great reference for those performing related activities, such as wildlife veterinarians, ecologists, officers, and rehabilitators.

The elbow disarticulation was performed in bear-01 because if a transhumeral amputation or scapulectomy was conducted, the surgical site could be broadened owing to the considerably thick upper limb and wide shoulder areas of the bear. Consequently, this might increase the surgery time and make post-operative management difficult. In addition, the advantage of elbow disarticulation in the bear was that the animal could use its upper limb after surgery, which could help it climb trees or balance on them, and this was confirmed as we observed that indeed the bear was climbing the tree using its amputated right limb. Additionally, there was little blood loss from vascular cutting during surgery, and there were no complications such as bleeding and formation of a seroma during the recovery period. This shows that using EVSD together rather than double ligation of vessels can help minimize bleeding in an amputation. Furthermore, the operation time was shortened by using EVSD without ligation before cutting the small vessels, and this is considered to be a very efficient method for long-term surgery of large animals.

In case 1 , the bear gave birth to two cubs after returning to its natural habitat despite being under a prolonged period of anesthesia and surgery. Considering that the day of the surgery and the day it was released into the wild were in late August and late October, respectively, the bear might have already had some fertilized eggs at the time of the operation; the ABBs in Korea only mate between May to August [21] and implantation in brown bears occurs in late November to early December $[22,23]$. It was reported that a high concentration of isoflurane negatively affects in vitro fertilization of inseminated oocytes in mice [24], but its correlation between anesthesia and development of a fertilized egg in bears is unknown. In case-01, we have confirmed the birth of two healthy cubs of a female bear that had fertilized eggs under prolonged anesthesia, and this supports the fact that the anesthesia protocol using zolazepam-tiletamine-isoflurane was safe in both $A B B$ and its fertilized eggs.

In case-02, we repaired the comminuted fracture of the left humerus in a bear and this is the first report on the treatment of humral fracture using dual plate fixation in bears. The unique and complex shape of the humerus makes fracture repairs challenging and the lateral aspect of the humerus is widely accepted as the tension side of the bone [25]. Similarly, in this case, large and thick muscles were attached to the humerus and there were strong muscle contractions and torsion with exuberant granulations. Moreover, since the bear was one of the animals that use their forelimbs frequently and are important for their survival, it was important to fix the bone fragments firmly during the recovery, and the repaired forelimb should be able to withstand the heavyweight of the bear itself, as well as the powerful forces that occur when the bear uses its forelimb. Thus, we used a locking compression plate (LCP), because it has advantages in comminuted fractures such as preservation of the blood supply by reducing the contact with the bone [26, 27], improvement of callus formation [28, 29 ] and no need for exact contouring of the plate which saves time and decreases the chances for loss of reduction [30]. Additionally, the LCP construction has four times more strength compared to conventional plating [31], but it does not depend on the screw purchase in the bone because the head of the screw fixes to the plate and as a result, is more advantageous in comminuted fractures [29, 32, 33]. Furthermore, we filled the mixture of autologous bone chips, synthetic hydroxyapatite, and rhBMP-2 in the bone defect areas. This trial would be helpful to accelerate bone formation and regeneration of defective bone tissues in the bear as well, although it was not clear how much it worked in this case. Because the osteogenic potential of BMP has been widely accepted and the suitability of hydroxyapatite as its carrier in rats, dogs, and cats including humans [34-38].

It was reported that $65 \%$ of long-bone fractured horses, including the humerus, showed complications after fracture repairing surgery [39]. In our case, no post-operative complications were observed during the stay during captivity and even after returning to nature. This successful treatment was possible not only because of the use of LCP and rhBMP-2 but also because the plates were applied dually and the exercise was restricted 
in a small cage after surgery. Although the application of a dual plate is not common in veterinary practice, Crawford and Fretz [39] reported that surgery with a dual plate had a higher success rate in the treatment of longbone fractured horses and cattle, and Bologna et al. [40] showed that the use of a dual plate showed a higher bone union rate than an operation with a single plate in humans.

For a seriously injured bear, the survival and recovery of its health are the most important proposition, but the most important thing to return to the wild after recovery of health is to behave like normal wild individuals and to show a tendency to avoid humans. Because any alterations of their behavior that make the bear more dependent on anthropogenic food sources or more exposed to humans will likely result in reduced survival [41]. Captive experience, in general, could negatively influence a bear's natural behavior in the wild and several studies reported unsuccessful reintroductions of captive bears [41-43]. That means it is difficult to maintain the wildness and natural behavior of bears in captivity. There is a limit to evaluating the home-range size of our released bears because a reference to the average home range size of $\mathrm{ABBs}$ in temperate forest areas is very rare, but comparing to the home-range size of American black bears in Washington [44] and Florida [45] in the U.S. (annual mean 95\% kernel home-range size of female and male in our cases, Washington and Florida were $265.8 \mathrm{~km}^{2}$ and $486.9 \mathrm{~km}^{2}$ vs $24.1 \pm 5.4 \mathrm{~km}^{2}$ and $96.6 \pm$ $26.5 \mathrm{~km}^{2}$ vs $24.2 \pm 3.6 \mathrm{~km}^{2}$ (female), respectively), bears in our cases seem to have a wide home-range and lots of movements despite the amputation of the leg or the implantation of the plates. This indicates that seriously injured bears fully recovered, but the question remains whether they were really well adapted to nature after releasing. Because home range size in bears subsequently varied from $2.4 \mathrm{~km}^{2}$ to $295 \mathrm{~km}^{2}$ [46-50] and could be influenced by several factors, including the distribution and abundance of resources, population density, degree of habitat fragmentation and associated anthropogenic effects $[44,45]$, so in addition to the home range, another indicator such as hibernation, mating, weight, disease infection and conflict with humans should be evaluated comprehensively to determine the natural adaptation after releasing. In our cases, the bears hibernated every winter, increased weight, gave birth to cubs (bear-01), were not found to have any abnormalities in the veterinary tests, and made no conflict issues with humans after releasing them into the wild. These facts support that our released bears adapted well to nature and that the way we took care of and rehabilitated the bears helped them return to nature.

A single bear's emergency rescue has a great impact on the restoration of the population in isolated habitats, not just on the animal at a humanitarian level. The rescue and returning to the nature of bear- 01 had the effect of saving five due to the birth of a total of four cubs twice after release. Also, bear-02 allowed the preservation of a male that can participate in breeding, thereby contributing to continued reproduction in and out of the habitat (1. natural reproduction within a population; 2 . when recaptured, semen collected at the site is frozen and can be used for assisted reproductive technology, such as artificial insemination and in vitro fertilization) $[51,52]$. In the long term, these two individuals have a preservative effect of at least 6 (bear-01 and its 4 cubs, bear-02) to about 15 individuals (Assumption 1, 10 years' breeding period; 2 , the male mate with at least one female per year; 3 , they are not defeated by the breeding competition; 4, female give birth every other year and have 2 cubs; 5 , the survival rate of the cubs is $50 \%$ ), and if individuals born by artificial insemination using semen of bear-02 are included, the preservative effect would be greater.

In conclusion, we showed the processes and results of a successful treatment, rehabilitation, and return to the wild of severely injured ABBs. We confirmed our surgical methods and post-operative managements were effective and even bears without one leg or with dual plates can adapt well in nature. Additionally, minimizing human contact and observing/evaluating behavior during the rehabilitation process is essential to reducing human-bear conflicts after release. Successful restoration of endangered species in isolated habitats requires that the project includes a team that can be fielded, as well as a specialized veterinary team, and continuous monitoring of the populations after release.

\section{Abbreviations}

ABB: Asiatic black bear; AST: Aspartate aminotransferase; CBC: Complete blood cell count; CCTV: Closed-circuit television system; DMD: Daily movement distances; $\mathrm{ETCO}_{2}$ : End-tidal carbon dioxide partial pressure; EVSD: Electro-thermal vessel sealing device; HR: Home range; LCP: Locking compression plate; MCP: Minimum convex polygons; NP: National Park; rhBMP-2: Recombinant human bone morphogenetic protein-2; $\mathrm{SpO}_{2}$ : Peripheral capillary oxygen saturation

\section{Acknowledgements}

The authors thank all staff members from the Wildlife Medical Center of the Korea National Park Service, Department of Veterinary Surgery and Biomaterial R\&BD Center of the Chonnam National University, and TDM Inc. for their assistance.

\section{Authors' contributions}

$\mathrm{DHJ}$ designed the study, operated injured bears and wrote the paper. KJ participated in the operation and post-operative process, and wrote the overall framework of this paper. JJY made significant contribution to drafting, editing the manuscript and supporting the operations. SHL performed clinical follow-up and data acquisition and contribution to editing of manuscript. JYC managed treated bears, radiotracked them after releasing into the wild and analyzed their movements and home ranges. SCY edited the manuscript and supported data analysis. KMS participated in the surgical procedure planning, operation and post-operative care in the case of the humerus fracture bear. SEK and SSK made substantial contributions to conception, design, 
analysis and writing process of the paper and operated on a bear with a fractured humerus. The author(s) read and approved the final manuscript.

\section{Funding}

This work conducted as part of a restoration project of endangered Asiatic black bears by the Ministry of Environment. In addition, this work was financially supported by a grant of the Korea Health Technology Development R\&D Project through the Korea Health Industry Development Institute (KHIDI), funded by the Ministry of Health \& Welfare, Republic of Korea (grant number: H19C0642), Rural Development Administration, Republic of Korea and Korea Institute of Planning and Evaluation for Technology in Food, Agriculture and Forestry (IPET) through Useful Agricultural Life Resources Industry Technology Development Program, funded by Ministry of Agriculture, Food and Rural Affairs (MAFR A)(120054021HD020). These three funders had no role in the study design, data collection and analysis, interpretation of the results, manuscript preparation, or decision to disseminate and publish the study findings.

\section{Availability of data and materials}

Not applicable.

\section{Declarations}

Ethics approval and consent to participate

All work reported in this study was carried out under license from the Korea National Park Service (permits SRTI-1727, 2783, 2924 and 3301).

\section{Consent for publication}

Not applicable.

\section{Competing interests}

The authors declare that they have no competing interests.

\section{Author details}

${ }^{1}$ Wildlife Medical Center, Korea National Park Service, Gurye 57616, Republic of Korea. ${ }^{2}$ Department of Veterinary Surgery and Biomaterial R\&BD Center, College of Veterinary Medicine, Chonnam National University, Gwanju 61186, Republic of Korea. ${ }^{3}$ Department of Veterinary Clinical Sciences and Research Institute for Veterinary Science, College of Veterinary Medicine, Seoul National University, 1 Gwanak-ro, Gwanak-gu, Seoul 08826, Republic of Korea.

Received: 21 November 2020 Accepted: 11 March 2021

Published online: 20 March 2021

\section{References}

1. Saran KA, Parker G, Parker R, Dickman CR. Rehabilitation as a conservation tool: a case study using the common wombat. Pac Conserv Biol. 2011;17(4): 310-9. https://doi.org/10.1071/PC110310.

2. Guy AJ, Curnoe D, Banks PB. A survey of current mammal rehabilitation and release practices. Biodivers Conserv. 2013;22(4):825-37. https://doi.org/10.1 007/s10531-013-0452-1.

3. Mullineaux E. Veterinary treatment and rehabilitation of indigenous wildlife. J Small Anim Pract. 2014;55(6):293-300. https://doi.org/10.1111/jsap.12213.

4. Dubois S, Fraser D. Conversations with stakeholders, part 1: goals, impediments, and relationships in wildlife rehabilitation. J Wildl Rehabil. 2003;26:14-22

5. Kirkwood JK, Sainsbury AW. Ethics of interventions for the welfare of freeliving wild animals. Anim Welf. 1996;5:235-43.

6. Miller EA. Minimum standards for wildlife rehabilitation. 3rd ed. St. Cloud: National Wildlife Rehabilitators Association; 2000.

7. Cant M. The rehabilitation of black bears (Ursus americanus) in North America: a survey of current practices. Thesis. Vancouver: The University of British Columbia; 2003. https://doi.org/10.14288/1.0165528.

8. Goodrich JM, Miquelle DG. Translocation of problem Amur tigers Panthera tigris altaica to alleviate tiger-human conflicts. Oryx. 2005;39(04):454-7. https://doi.org/10.1017/S0030605305001146.

9. Soorae PS. Placement options for confiscated bears. In: Kolter L, Dijk J, editors. Rehabilitation and release of bears. For the welfare of conservation or for the conservation of welfare? Köln: Zoologischer Garten Köln; 2005. p. $17-27$.
10. Beecham JJ, Hernando MG, Karamanlidis AA, Beausoleil RA, Burguess K, Jeong $\mathrm{DH}$, et al. Management implications for releasing orphaned, captivereared bears back to the wild. J Wildl Manag. 2015;79(8):1327-36. https:// doi.org/10.1002/jwmg.941.

11. Garshelis DL, Steinmetz R. 2020. Ursus thibetanus (amended version of 2016 assessment). The IUCN red list of threatened species 2020: e. T22824A166528664. https://doi.org/10.2305/IUCN.UK.2020-3.RLTS.T22824A1 66528664.en. Accessed 28 Feb 2021.

12. Jeong $\mathrm{DH}$, Yang DH, Lee BK. Re-introduction of the Asiatic black bear into Jirisan National Park, South Korea. In: Prital S (ed) IUCN Global reintroduction perspectives 2010. https://www.iucn.org/content/global-reintroduction-perspectives-2010-additional-case-studies-around-globe. Accessed 02 Mar 2021.

13. Song DJ: Restoration Ecology of the Ussuri Black Bear (Ursus thibetanus ussuricus) at Jiri-san. http://dcollection.kangwon.ac.kr/common/orgView/ 000000031173 (2020). Accessed 02 Mar 2021.

14. Jeong DH, Yang JJ, Seok SH, Song DJ, Yeon SC. Cardiorespiratory effects of isoflurane in Asiatic black bears (Ursus thibetanus) anesthetized with intramuscular medetomidine and zolazepam/tiletamine. J Vet Med Sci. 2017;79(1):153-9. https://doi.org/10.1292/jvms.16-0290.

15. Winkler W. Procedure in amputation of the upper arm, elbow exarticulation and forearm amputation. Helv Chir Acta. 1988;54(6):741-5.

16. Morrey BF. Surgical exposures of the elbow. In: Morrey BF, editor. The elbow and its disorders. 4th ed. Philadelphia: Saunders Elsvier; 2009. p. 115-42. https://doi.org/10.1016/B978-1-4160-2902-1.50012-7.

17. Yang $\mathrm{DH}$, Kim BH, Jung DH, Jeong DH, Jeong WJ, Lee BG. The studies on characteristics of home range size and habitat use of the Asiatic black bear released in Jirisan. Korean J Environ Ecol. 2008;22:427-34.

18. Clark JE, Pelton MR, Wear BJ, Ratajczak DR. Survival of orphaned black bears released in the Smoky Mountains. Ursus. 2002;13:269-73.

19. Smith WE, Pekins JP, Timmins AA, Kilham B. Short-term fate of rehabilitated orphan black bears released in New Hampshire. Hum-Wildl Interact. 2016;10: 258-67. https://doi.org/10.26077/grqp-ty92.

20. Blair CD, Muller L, Clark JD, Stiver WH. Survival and conflict behavior of American black bears after rehabilitation. J Wildl Manag. 2019;84(1):75-84. https://doi.org/10.1002/jwmg.21783.

21. Kim MW, Jeong DH, Yeon SC. Sexual behavior and ethogram of the Asiatic black bear (Ursus thibetanus). J Vet Behav. 2020;37:20-6. https://doi.org/10.1 016/j.jveb.2020.04.007.

22. Hensel RJ, Troyer WA, Erickson AW. Reproduction in the female brown bear. J Wildl Manag. 1969;33(2):357-65. https://doi.org/10.2307/3799836.

23. Tsubota T, Kanagawa H. Morphological characteristics of the ovary, uterus and embryo during the delayed implantation period in the Hokkaido brown bear (Ursus arctos yesoensis). J Reprod Develop. 1993;39(4):325-31. https://doi.org/10.1262/jrd.39.325.

24. Kim JH, Lee $\mathrm{CH}$. The effects of volatile anesthesics and narcotics on in vitro fertilization of mouse oocytes. Korean J Anesthesiol (former The Journal of the Korean Society of Anesthesiologists). 1993;26(6):1087-103. https://doi. org/10.4097/kjae.1993.26.6.1087.

25. Simpson AM. Fractures of the humerus. Clin Tech Small Anim Pract. 2004; 19(3):120-7. https://doi.org/10.1053/j.ctsap.2004.09.004.

26. Perren SM, Klaue K, Pohler O, Predieri M, Steinemann S, Gautier E. The limited contact dynamic compression plate (LC-DCP). Arch Orthop Trauma Surg. 1990;109(6):304-10. https://doi.org/10.1007/BF00636166.

27. Leunig M, Hertel R, Siebenrock K, Balmer F, Mast J, Ganz R. The evaluation of indirect reduction techniques for the treatment of fractures. Clin Orthop Relat Res. 2000;375:7-14. https://doi.org/10.1097/00003086-200006000-00003.

28. Bolhofner BR, Carmne B, Clifford P. The results of open reduction and internal fixation of distal femur fractures using biologic (indirect) reduction technique. J Orthop Trauma. 1996;10(6):372-7. https://doi.org/10.1097/ 00005131-199608000-00002.

29. Greiwe RM, Archdeacon MT. Locking plate technology: current concepts. J Knee Surg. 2007;20(01):50-5. https://doi.org/10.1055/s-0030-1248022.

30. Miller DL, Goswami T. A review of locking compression plate biomechanics and their advantages as internal fixators in fracture healing. Clin Biomech. 2007;22(10):1049-62. https://doi.org/10.1016/j.clinbiomech.2007.08.004.

31. Gautier E, Perren SM, Cordey J. Strain distribution in plated and unplated sheep tibia. An in vivo experiment. Injury. 2000;31(Suppl 3):C37-44. https:// doi.org/10.1016/S0020-1383(00)80030-3.

32. Fulkerson E, Egol KA, Kubiak EN, Liporace F, Kummer FJ, Koval KJ. Fixation of diaphyseal fractures with a segmental defect: a biomechanical comparison 
of locked and conventional plating techniques. J Trauma. 2006;60(4):830-5. https://doi.org/10.1097/01.ta.0000195462.53525.0c.

33. Gardner MJ, Griffith MH, Demetrakopoulos D, Brophy RH, Grose A, Helfet DL, et al. Hybrid locked plating of osteoporotic fractures of the humerus. J Bone Joint Surg Am. 2006;88(9):1962-7. https://doi.org/10.2106/JBJS.E.00893.

34. Noshi T, Yoshikawa T, Ikeuchi M, Dohi Y, Ohgushi H, Horiuchi K, Sugimura $\mathrm{M}$, Ichijima K, Yonemasu K. Enhancement of the in vivo osteogenic potential of marrow/hydroxyapatite composites by bovine bone morphogenetic protein. J Biomed Mater Res. 2000;52(4):621-30. https://doi. org/10.1002/1097-4636(20001215)52:4<621::AID-JBM6>3.0.CO;2-A.

35. Alam Ml, Asahina I, Ohmamiuda K, Takahashi K, Yokota S, Enomoto S. Evaluation of ceramics composed of different hydroxyapatite to tricalcium phosphate ratios as carriers for rhBMP-2. Biomaterials. 2001;22(12):1643-51. https://doi.org/10.1016/50142-9612(00)00322-7.

36. Ohta H, Wakitani S, Tensho K, Horiuchi H, Wakabayashi S, Saito N, Nakamura Y, Nozaki K, Imai Y, Takaoka K. The effects of heat on the biological activity of recombinant human bone morphogenetic protein-2. J Bone Miner Metab. 2005;23(6):420-5. https://doi.org/10.1007/s00774-005-0623-6.

37. Rohanizadeh R, Chung K. Hydroxyapatite as a carrier for bone morphogenetic protein. J Oral Implantol. 2011;37(6):659-72. https://doi. org/10.1563/AAID-JOI-D-10-00005.

38. Pinel CL, Pluhar GE. Clinical application of recombinant human bone morphogenetic protein in cats and dogs: a review of 13 cases. Can Vet J. 2012:53(7):767-74.

39. Crawford WH, Fretz PB. Long bone fractures in large animals: a retrospective study. Vet Surg. 1985;14(4):295-302. https://doi.org/10.1111/j.1532-950X.1 985.tb00889.x.

40. Bologna MG, Claudio MG, Shields K, Katz C, Salopek T, Westrick ER. Dual plate fixation results in improved union rates in comminuted distal femur fractures compared to single plate fixation. J Orthop. 2019;8:76-9. https:// doi.org/10.1016/j.jor.2019.09.022.

41. Clark JD, Huber D, Servheen C. Bear reintroductions: lessons and challenges. Ursus. 2002;13:335-45.

42. Buchalczyk T. The brown bear in Poland. Bears: their biology and management. 1980;4:229-32. https://doi.org/10.2307/3872872.

43. Jule KR, Leaver LA, Lea SEG. The effects of captive experience on reintroduction survival in carnivores: a review and analysis. Biol Conserv. 2008;141(2):355-63. https://doi.org/10.1016/j.biocon.2007.11.007.

44. Koehler GM, Pierce DJ. Black bear home-range sizes in Washington: climatic, vegetative, and social influences. J Mammal 2003;84:81-91. https://doi.org/1 0.1644/1545-1542(2003)084<0081:BBHRSI>2.0.CO;2, 1 .

45. Moyer MA, Mccown JW, Oli MK. Factors influencing home-range size of female Florida black bears. J Mammal. 2007;88(2):468-76. https://doi.org/1 0.1644/06-MAMM-A-165R1.1.

46. Lindzey FG, Meslow EC. Home range and habitat use by black bears in southwestern Washington. J Wildl Manag. 1977;41(3):413-25. https://doi. org/10.2307/3800510.

47. Alt GL, Matula GJ, Alt FW, Lindzey JS. Dynamics of home range and movements of adult black bears in northeastern Pennsylvania. Bears: their biology and management. 1980;4:131-6. https://doi.org/10.2307/3872856.

48. Pacas CJ, Paquet PC. 1994. Analysis of black bear home range using a geographic information system. Bears: their biology and management. 1994;9:419-25. https://doi.org/10.2307/3872728.

49. Hirsch JG, Bender LC, Haufler JB. Black bear, Ursus americanus, movements and home ranges on Drummond island. Michigan Can field-nat. 1999;113: 221-5.

50. Oli MK, Jacobson HA, Leopold BD. Pattern of space use by female black bears in the White River National Wildlife Refuge, Arkansas, USA. J Nat Conserv. 2002;10(2):87-93. https://doi.org/10.1078/1617-1381-00010.

51. Okano T, Murase T, Tsubota T. Electroejaculation and semen cryopreservation of free-ranging Japanese black bears (Ursus thibetanus japonicus). J Vet Med Sci. 2004;66(11):1371-6. https://doi.org/10.1292/jvms. 66.1371.

52. Jeong DH, Yang JJ, Seo MK, Lee AN, Lim YK. Effectiveness of urethral catheterization under ultrasound guidance for semen collection from Asiatic black bears (Ursus thibetanus). Theriogenology. 2019;129:154-9. https://doi. org/10.1016/j.theriogenology.2019.02.032.

\section{Publisher's Note}

Springer Nature remains neutral with regard to jurisdictional claims in published maps and institutional affiliations.

Ready to submit your research? Choose BMC and benefit from:

- fast, convenient online submission

- thorough peer review by experienced researchers in your field

- rapid publication on acceptance

- support for research data, including large and complex data types

- gold Open Access which fosters wider collaboration and increased citations

- maximum visibility for your research: over $100 \mathrm{M}$ website views per year

At BMC, research is always in progress.

Learn more biomedcentral.com/submissions 